\title{
Pengembangan Perangkat Pembelajaran Matematika Menggunakan Pendekatan Neuroscience pada Siswa Kelas V Sekolah Dasar
}

\author{
Sirwanti \\ STKIP Muhammadiyah Bone \\ sirwanti89@gmail.com
}

\begin{abstract}
ABSTRAK
Matematika masih merupakan pelajaran yang kurang disukai oleh siswa sehingga perlu adanya inovasi pembelajaran yang dapat dikemas sebaik mungkin agar dapat mudah dipahami oleh siswa. Salah satu ilmu yang berkembang pada akhir-akhir ini dam proses pembelajaran adalah neuroscience. Pandangan mengenai keterkaitan neuroscience dalam proses belajar mengajar telah banyak dilakukan dan sangat berpengaruh baik untuk melatih siswa dalam menggunakan otak dalam belajar. Pendekatan dalam pembelajaran neuroscience tidak dapat berdiri sendiri, untuk itu guru juga dituntut untuk mampu menggunakan perangkat pembelajaran yang inovatif agar proses pembelajaran yang berlangsung dapat lebih bermakna dan melekat dalam ingatan siswa. Oleh karena itu, inovasi untuk mengefektifkan pembelajaran yaitu dengan mengembangkan perangkat pembelajaran matematika di sekolah dasar yang disandingkan dengan pendekatan neuroscience dalam pembelajaran. Penelitian ini adalah penelitian pengembangan yang bertujuan untuk menghasilkan perangkat pembelajaran matematika menggunakan pendekatan neuroscience yang memenuhi kriteria valid, praktis dan efektif. Produk yang dikehendaki dalam penelitian ini adalah perangkat pembelajaran yang valid, praktis, dan efektif. Produk tersebut terdiri dari lima komponen yaitu: Rencana Pelaksanaan Pembelajaran (RPP) dan Lembar Kerja Siswa (LKS). Proses pengembangan perangkat pembelajaran menggunakan model 4-D Thiagarajan yang terdiri dari 4 tahap yaitu tahap pendefinisian (define), perancangan (design), pengembangan (develop), dan penyebaran (disseminate).
\end{abstract}

Kata kunci: Pengembangan perangkat, pembelajaran matematika, pendekatan neuroscience

\section{PENDAHULUAN}

Matematika sebagai ilmu dasar merupakan suatu alasan pembelajaran matematika dikemas sebaik mungkin agar mudah dipahami oleh siswa. Hal ini terlihat dari pendidikan di jenjang Sekolah Dasar, siswa masih kesulitan mengingat materi ajar matematika karena konsep-konsep matematika yang dipelajari cenderung merangsang otak kiri yang hanya dihafalkan tanpa dipahami terlebih dahulu, sehingga pemberian soal sejenis siswa akan kesulitan mengingat konsep/formula untuk penyelesaian soal. Pelaksanaan pembelajaran matematika, dirasakan masih dominan penggunaan otak kiri mulai dari mendengarkan guru, menulis/mencatat, berpikir tentang apa yang disampaikan guru, berdiskusi dan dipenuhi oleh latihan-latihan yang bersifat mekanistik (hitung menghitung saja) sehingga cenderung membosankan. Hal ini berakibat siswa sangat jarang mendapatkan kesempatan untuk melakukan kegiatan eksplorasi/penemuan yang menantang dan memotivasi semangat belajarnya. Pengetahuan mengembangkan perangkat pembelajaran yang inovatif bagi guru masih rendah sehingga guru masih kesulitan mengembangkan ataupun memodifikasi perangkat pembelajaran yang sesuai dengan kondisi kelas. Hal ini disebabkan guru jarang mengikuti kegiatan-kegiatan ilmiah terkait pengembangan model maupun perangkat pembelajaran. Sehingga tidak menyediakan perangkat pembelajaran yang sesuai dengan kebutuhan siswa.

Salah satu ilmu yang berkembang pada akhirakhir ini adalah neuroscience. Ilmu ini telah 
berkembang cukup lama, hanya saja penelitianpenelitian terhadap otak lebih dicurahkan untuk topik-topik disfungsi otak. Seiring pesatnya kemajuan teknologi menghasilkan metodemetode baru yang dapat menununjukkan bagaimana otak menjalankan fungsi-fungsinya di saat menjalankan kerja-kerja mental yang melibatkan pembelajaran dan memori. Berdasarkan hasil penerapan metode-metode dalam neuroscience sangat relevan dengan pembelajaran di kelas dan memberikan implikasi bagi pembelajaran, motivasi dan perkembangan. Selain itu dipilihnya neuroscience sebagai basis pengembangan perangkat pembelajaran didasarkan pendapat Schunk (2012:42) bahwa pengetahuan, perasaan dan tindakan rata-rata kaitanya dengan kinerja otak, karena pada dasarnya proses kognitif yang meliputi pikiran, keyakinan dan emosi semuanya memiliki representasi-representasi yang terakit dengan saraf. Pembelajaran berbasis neuroscience merupakan sistem pendidikan baru yang memelajari tentang sistem kerja syaraf yang dipadukan dalam bidang pendidikan (Wathon, 2012).

Pandangan mengenai keterkaitan neuroscience dalam proses belajar mengajar telah banyak dilakukan dan sangat berpengaruh baik untuk melatih siswa dalam menggunakan otak dalam belajar. Masson (2012) menjelaskan neuroscience tidak hanya memandang bahwa bagaimana otak diajarkan sebuah pengetahuan baru, melainkan menggunakan otak bekerja sebagaimana fungsinya. Pendekatan dalam pembelajaran neuroscience tidak dapat berdiri sendiri, untuk itu guru juga dituntut untuk mampu menggunakan perangkat pembelajaran yang inovatif agar proses pembelajaran yang berlangsung dapat lebih bermakna dan melekat dalam ingatan siswa. Beberapa teknik dalam pembelajaran neuroscience yang dapat diintegrasikan dalam perangkat pembelajarannya untuk melatih siswa dalam mengingat sebuah materi pelajaran sehingga diharapkan daya ingat siswa dalam memahami dan mengingat pembelajaran bertahan lama. Oleh karena itu, untuk mewujudkan hal tersebut, peneliti mencoba akan mengembangkan perangkat pembelajaran matematika menggunakan pendekatan neuroscience pada siswa Sekolah Dasar di kabupaten Bone.

Berdasarkan rumusan masalah penelitian yang akan diteliti dapat disimpulkan bahwa tujuan penelitian adalah: 1) Untuk mengetahui kevalidan hasil pengembangan perangkat pembelajaran matematika menggunakan pendekatan neuroscience?; 2) Untuk mengetahui kepraktisan hasil pengembangan hasil pengembangan perangkat pembelajaran matematika menggunakan pendekatan neuroscience?; 3) Untuk mengetahui aktivitas guru dalam mengelola pembelajaran matematika menggunakan pendekatan neuroscience?; 4) Untuk mengetahui aktivitas siswa dalam mengelola pembelajaran matematika menggunakan pendekatan neuroscience?; 5) Untuk mengetahui respons siswa terhadap pembelajaran matematika menggunakan pendekatan neuroscience?; 6) Untuk mengetahui hasil belajar siswa dalam pembelajaran matematika menggunakan pendekatan neuroscience?

\section{Perangkat Pembelajaran}

Perangkat dalam Bahasa Inggris diartikan sebagai devicesyang dalam Oxford Advanced Learner's Dictionary didefenisikan sebagai an object or a piece of equipment that has been designed to do a particular job yang berarti bahwa sebuah objek atau seperangkat alat yang didesain untuk melakukan pekerjaan tertentu.

Pembelajaran (learning) menurut Santrock (2007) mendefinisikan sebagai pengaruh yang relatif permanen atas perilaku, pengetahuan, dan keterampilan berpikir, yang diperoleh melalui pengalaman. Menurut Sirwanti (2016) pembelajaran atau pengajaran adalah upaya untuk membelajarkan siswa dimana dalam pengertian ini secara implisit dalam pengajaran terdapat kegiatan memilih, menetapkan, mengembangkan metode untuk mencapai hasil pengajaran yang diharapkan

Berdasarkan uraian di atas dapat disimpulkan bahwa perangkat pembelajaran adalah sekumpulan sumber belajar yang menunjang terlaksananya pembelajaran dengan baik. Perangkat pembelajaran dalam penelitian ini 
adalah Rencana Pelaksanaan Pembelajaran (RPP), Lembar Kerja(LK) dan Buku Siswa (BS).

Pengembangan pembelajaran secara prosedural digambarkan secara sistematis dalam perangkat pembelajaran. Pengembangan perangkat pembelajaran untuk meningkatkan hasil belajar matematika siswa didasarkan pada pembelajaran sebagai sistem, yang mempertimbangkan komponen raw input (siswa sebagai pembelajar), enviiromental input (tuntutan lingkungan masyarakat dan perbaikan mutu pendidikan), instrumental input (kebijakan pendidikan), kemudian merancang/desain dan implementasi proses pembelajaran (process), sehingga dihasilkan siswa yang memiliki kemampuan penalaran matematika dalam memecahkan persoalan matematika (output).

\section{Penilaian Kualitas Perangkat Pembelajaran}

Penilaian kualitas produk pengembangan dapat mengacu kepada kriteria kurikulum yang dikemukakan Nieveen. Menurutnya validitas ditentukan berdasarkan pada rasional teoritis yang kuat dan memiliki konsistensi internal. Kepraktisan ditentukan dengan menggunakan dua kriteria yaitu (1) produk yang dikembangkan dapat diterapkan menurut penilaian ahli atau praktisi, (2) produk yang dikembangkan dapat diterapkan secara rill di lapangan. Keefektifan ditentukan oleh dua kriteria, yaitu (1) efektif menurut penilaian dan pengembangan ahi atau praktisi, dan (3) dapat memberikan hasil sesuai dengan harapan (Nurdin: 2007)

Penilaian perangkat pembelajaran mengacu pada kriteria kualitas kurikulum yaitu validitas, kepraktisan, dan keefektifan.Berdasarkan pendapat Nievenn dalam Nurdin (2007), maka perangkat pembelajaran dikatakan berkualitas jika memenuhi kriteria-kriteria berikut; 1) Menurut penilaian ahli atau praktisi, secara teoritis model tersebut dapat terlaksana dengan baik (valid); 2) Perangkat yang dikembangkan dapat terlaksana dengan baik di lapangan (kepraktisan) dengan menggunakan indikator keterlaksanaan pembelajaran dalam hal ini kemampuan pengelolan pembelajaran; 3) Implementasi perangkat memberikan hasil yang optimal (efektif) dengan menggunakan tes hasil belajar, kemampuan pendidik

\section{Pengembangan Perangkat Pembelajaran}

Menurut Sugiyono (2012: 407) penelitian pengembangan adalah metode penelitian yang digunakan untuk menghasilkan produk tertentu dan menguji keefektifan produk tersebut. Jadi dapat disimpulkan bahwa pengembangan adalah serangkaian kegiatan yang dilakukan untuk menghasilkan sesuatu, dalam hal ini perangkat pelajaran berdasarkan salah satu teori pengembangan yang telah dipilih.

Pengembangan perangkat pembelajaran menggunakan pendekatan scientific setting kooperatif yang digunakan dalam penelitian ini mengacu pada Model Triagarajan (4-D).yang terdiri dari empat macam tahap pengembangan yakni, Pendefinisian (Define), Perancangan (Design), Pengembangan (Develop), dan Penyebaran (Desseminates) (Sirwanti 2016).

\section{Pembelajaran Matematika}

Matematika merupakan suatu bahan kajian yang memiliki obyek abstrak dan dibangun melalui proses penalaran deduktif, yaitu kebenaran suatu konsep diperoleh sebagai akibat logis dari kebenaran sebelumnya yang sudah diterima, sehingga keterkaitan antar konsep dalam matematika bersifat sangat kuat dan jelas (konsisten). Namun demikian, pembelajaran dan pemahaman konsep dapat diawali secara induktif melalui pengalaman peristiwa nyata atau intuisi.

\section{Pendekatan Neuroscience}

Istilah Neuroscience merupakan cabang ilmu yang khusus mengkaji tentang studi saintifik dari sistem syaraf otak. Komunitas neuroscience didirikan pada tahun 1969, namun pembelajaran mengenai otak sudah dilakukan sejak lama. Secara tradisional disiplin ilmu yang mengkaji tentang neuroscience terlihat seperti cabang dari ilmu biologi. Namun menurut (Munandar, 2011).pada kenyataan dalam perkembangannya neuroscience lebih dari sekedar ilmu biologi, lebih membahas mengenai fungsi syaraf otak, terkait dalam pendidikan maupun di luar ilmu pendidikan.

Neuro berarti sel syaraf otak, bagaimana sel-sel tersebut mencatat atau merekam informasi di sekitar manusia setelah mendapatkan stimulus. Berdasarkan para ahli neuroscience, sel syaraf otak 
manusia menerima empat juta item informasi per detiknya. Informasi tersebut masuk ke dalam alam pikiran manusia melalui peran sel-sel syaraf atau akson. neuro berarti bagaimana sel-sel syaraf otak menerima informasi. Setelah muncul dari beberapa pengertian tentang neuro dan pedagogis, dapat disimpulkan bahwa neuropedagogis bisa disebut juga neuroeducation yaitu interdisipliner yang menggabungkan bidang neuroscience, psikologi dan pendidikan untuk menciptakan peningkatan pengajaran metode dan kurikulum dalam penelitian dan inisiatif untuk menggunakan penemuan tentang belajar, memori, bahasa dan daerah lain (Nuraeni, 2014).

Tahun 1990-an pertama kali dilakukan penelitian yang menghubungkan antara neuroscience dan pendidikan. Hubungan ini tentang bagaimana fungsi sistem neuron pada anak-anak, dan dikenal dengan istilah "pendidikan berbasis otak". Konsep neuroscienceyang dijelaskan merupakan suatu bidang kajian mengenai sistem saraf yang terdapat di dalam otak manusia yang berhubungan dengan kesadaran dan kepekaan otak dari segi biologi, persepsi, ingatan, dan kaitannya dengan pembelajaran (Rudi, 2015:3).

Cercone (2008) menjelaskan bahwafakta ilmiah menunjukkan bahwa perubahan fisik dan neurologis yang terjadi seiring bertambahnya usia akan mempengaruhi bagaimana manusia belajar. Kognitif neuroscience dalam penelitianpendidikanbertujuan untuk menginformasikan pendidik mengenai strategi terbaik untuk mengajar dan belajar. Semakin banyak guru ingin tahu bagaimana siswa berfikir dan belajar, (Nuraeni, 2014).

Penelitian dalam bidang neuroscience tentang bagaimana fungsi otak merupakan kajian yang menarik. Pengetahuan orang tentang otak, diperoleh dari proses pengkajian selama ratusan tahun. Penemuan penting tentang neuroscience dimulai ketika Cajal, seorang ilmuwan Spanyol pemenang Nobel 1906 menemukan empat doktrin neuron. Kemudian Charles Sherrigon menemukan bahwa neuron tidak hanya dapat bersifat aktif (mengirimkan sinyal 0 ), tapi juga ada yang menggunakan terminal. neuroscience merupakan bidang kajian sistem saraf otak manusia yang berhubungan dengan kesadaran dan kepekaan otak dari segi biologi, persepsi, ingatan, dan pembelajaran (Rudi, 2015).

Berdasarkan uraian di atas, dapat disimpulkan bahwa neuroscience yaitu interdisipliner yang menggabungkan bidang neuroscience, psikologi dan pendidikan untuk menciptakan peningkatan pengajaran metode dan kurikulum dalam penelitian dan inisiatif untuk menggunakan penemuan tentang belajar dan memori. neuroscience merupakan sistem pembelajaran yang menekankan pada penggunaan otak sebagaimana fungsinya

Pandangan mengenai keterkaitan neuroscience dalam proses belajar mengajar telah banyak dilakukan dan sangat berpengaruh baik untuk melatih siswa dalam menggunakan otak dalam belajar. Masson (2012) menjelaskan neuroscience tidak hanya memandang bahwa bagaimana otak diajarkan sebuah pengetahuan baru, melainkan menggunakan otak bekerja sebagaimana fungsinya. Pendekatan dalam pembelajaran neurosciencet idak dapat berdiri sendiri, untuk itu guru juga dituntut untuk mampu menggunakan perangkat pembelajaran yang inovatif agar proses pembelajaran yang berlangsung dapat lebih bermakna dan melekat dalam ingatan siswa. Beberapa teknik dalam pembelajaran neuroscience yang dapat diintegrasikan dalam perangkat pembelajarannya untuk melatih siswa dalam mengingat sebuah materi pelajaran sehingga diharapkan daya ingat siswa dalam memahami dan mengingat pembelajaran bertahan lama.

Menurut Suyadi (2012) pengembangan lebih lanjut dari jejak ini adalah ekspansi neuroscience di bidang pendidikan yang menghasilkan teoriteori pembelajaran quantum. (Suryadi, 2012). Implikasi neuroscience dalam pendidikan adalah sebagai berikut: 1) Optimalisasi kecerdasan; 2) Keseimbangan fungsi otak kanan dan kiri; 3) Keseimbangan otak triune; 4) Pengembangan motorik tangan; 5) Pengembangan kemampuan berbahasa; 6) Multiple intelligences (MI), 7) Belajar sepanjang hayat

Prosedur pembelajaran neuroscience dalam perangkat pembelajaranyang diadaptasi dari 
beberapa model pembelajaran yang lebih mengutamakan fungsi otak dalam pembelajaran, tahapan tersebut ada tujuh tahapan pembelajaran berbasis kemampuan otak (Rudi, 2015), sebagai berikut: 1) Pra-Pemaparan. Tahap ini memberi gambaran awal terhadap pembelajaran baru sebelum dikaji lebih jauh dan mendalam. Pra-pemaparan membantu otak membangun peta konseptual yang lebih baik, 2) Persiapan. Dalam tahap ini, Fasilitator menciptakan keingintahuan dan kesenangan; 3) Inisiasi dan akuisisi. Tahap ini merupakan tahap penciptaan koneksi atau pada saat neuronneuron itu saling "berkomunikasi" satu sama lain; 4) Elaborasi. Tahap elaborasi memberikan kesempatan kepada otak untuk menyortir, menyelidiki, menganalisis, menguji, dan memperdalam pembelajaran; 5) Inkubasi dan memasukkan memori. Tahap ini menekankan bahwa waktu istirahat dan waktu untuk mengulang kembali merupakan suatu hal yang penting; 6) Verifikasi dan pengecekan keyakinan. Dalam tahap ini, fasilitator mengecek apakah peserta sudah paham dengan materi yang telah dipelajari atau belum; 7) Perayaan dan integrasi. Tahap ini menanamkan semua arti penting dari kecintaan terhadap belajar.

Proses desain pengembangan perangkat pembelajaran berbasis neuroscience dapat digambarkan sebagai berikut.

Analisis Kebutuhan

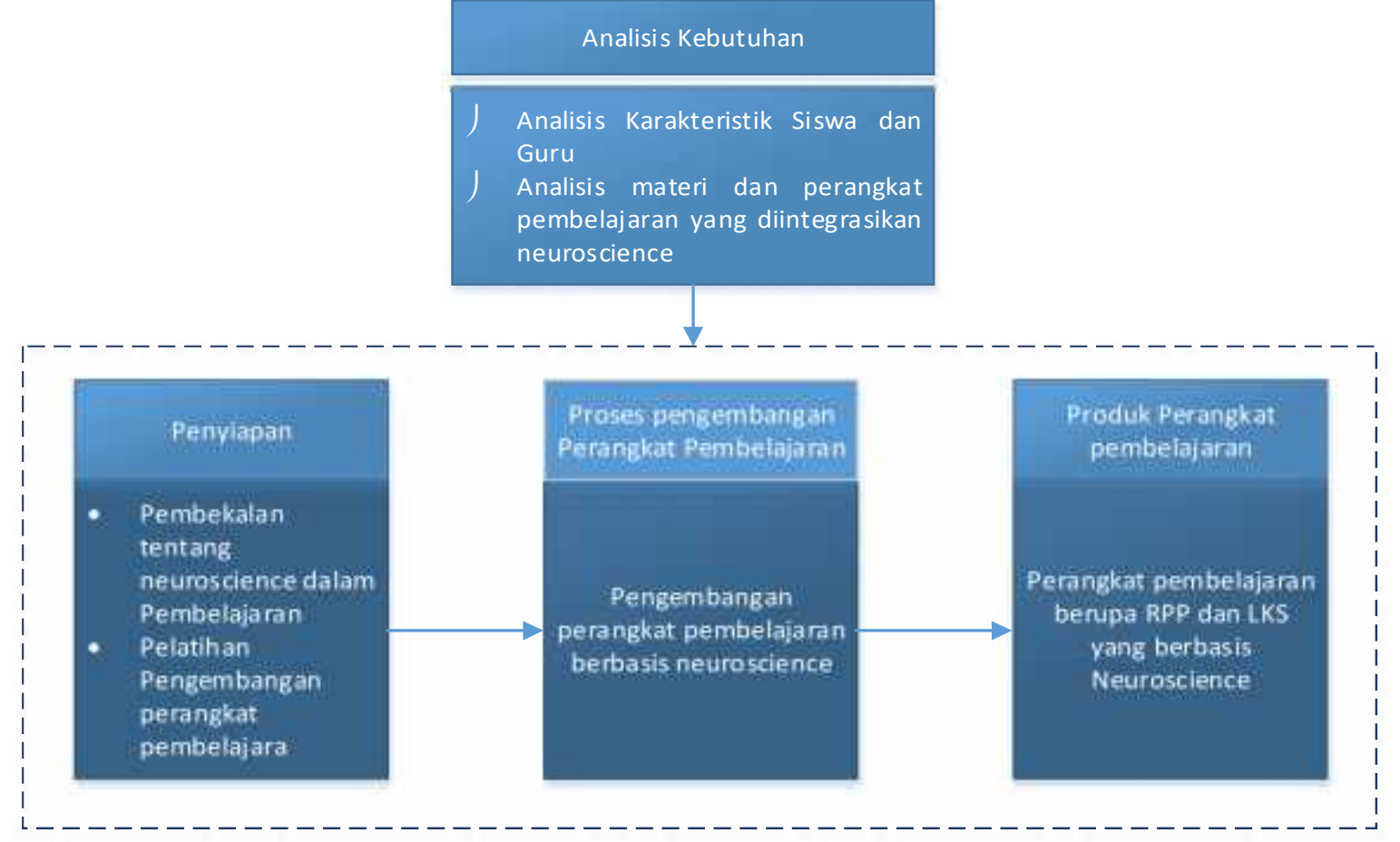

Gambar 1. Proses Desain Pengembangan Pembelajaran Berbasis Neuroscience

\section{METODE PENELITIAN}

Jenis penelitian ini adalah penelitian Pengembangan (Development) yang mengembangkan dan mendesain perangkat pembelajaran matematika yang meliputi pengembangan perangkat pembelajaran yang terdiri atas Buku Siswa (BS), Rencana Pelaksanaan Pembelajaran (RPP), dan Lembar Kerja Peserta Didik (LKPD). Penelitian ini dilaksanakan di SDN 42 Waetwo, dan subjek dalam penelitian ini adalah siswa kelas $\mathrm{Va}$ dan $\mathrm{b}$ dilaksanakan pada semester genap tahun ajaran
2017/2018 melalui tiga tahap yakni tahap persiapan, tahap pelaksanaan dan tahap analisis data.

Adapun cara pengumpulan data yang dilakukan dalam penelitian ini adalah sebagai berikut. (a) Data mengenai aktivitas siswa dan kemampuan guru dalam kegiatan proses pembelajaran, diperoleh dari lembar observasi (pengamatan) aktivitas siswa. (b) Data akhir pembelajaran hasil belajar diperoleh melalui tes. (c) Data mengenai respons siswa terhadap pembelajaran berbasis model pembelajaran 
matematika menggunakan pendekatan neuroscience setting koperatif melalui angket respons siswa.

Adapun teknik analisis data yang digunakan sebagai berikut: (1) Data hasil penilaian kevalidan perangkat pembelajaran oleh dua validator/ ahli, yaitu orang yang dipandang ahli dalam bidang pendidikan matematika, (2) Data keparaktisan perangkat pembelajaran matematika menggunakan pendektan neuroscience adalah data dari keterlaksanaan pembelajaran program linear secara umum dari dua observer yang dinalisis secara kualitatif. Hasil yang diperoleh pada tiap-tiap pertemuan akan ditentukan berdasarkan nilai rata-rata dari pertemuan pertama sampai pertemuan keempat, (4) Indikator keefektifannya adalah (1) Ketercapaian hasil belajar(2) Aktivitas siswa (3) Respons Siswa

\section{HASIL DAN PEMBAHASAN \\ Hasil Analisis Data}

Tahap I : Pendefinisian (Define): 1) Hasil Analisis pendahuluan, Analisis pendahuluan dilakukan untuk menetapkan masalah dasar yang menjadi perlu tidaknya dikembangkan perangkat pembelajaran matematika menggunakan pendekatan neuroscience. Berdasarkan telaah terhadap pelaksanaan dan hasil pembelajaran matematika di SDN 42 Waetwo Kabupaten Bone ternyata kesalahan mendasar yang perlu diupayakan pemecahannya adalah rendahnya prestasi belajar matematika yang dicapai oleh siswa. Selama ini proses pembelajaran di kelas cenderung didominasi oleh guru, siswa hanya mendengarkan dan mencatat apa yang disampaikan oleh guru. Hal ini tentu membuat siswa akan terkesan pasif dalam pembelajaran sehingga siswa kurang memperoleh kesempatan yang cukup untuk mengembangkan kemampuannya sendiri. Ada beberapa masalah dasar yang dihadapi dalam pembelajaran matematika ini, diantaranya yaitu (1) Kebanyakan siswa menanyakan pentingnya belajar matematika,(2) Pemilihan model dan pendekatan pembelajaran yang kurang sesuai dengan materi pembelajaran, (3) Belum adanya Buku Siswa (BS) serta Lembar Kerja Peserta
Didik (LKPD) sebagai sumber belajar yang membantu siswa dalam memahami pelajaran. Hal ini merupakan dampak dari penggunaan pembelajaran yang sering dilakukan oleh guru. Oleh karena itu, penulis mengambil alternatif pembelajaran matematika yang mengembangkan perangkat pembelajaran matematika menggunakan pendekatan neuroscience yang di setting secara kooperatif. Sehingga pembelajaran tidak lagi berpusat pada guru melainkan berpusat pada siswa (student centered); 2) Hasil Analisis materi, Analisis materi dalam pengembangan perangkat pembelajaran matematika ini adalah materi bangun ruang. Pemilihan materi ini cocok digunakan dengan pendekatan neuroscience karena siswa dapat bekerja sama dalam kelompok menyelesaikan masalah atau fenomena operasi matematika pokok bahasan bangun ruang kelas V SD; 3) Hasil Analisis tugas, Karakteristik yang digunakan dalam analisis tugas ini sesuai dengan pokok bahasan bangun ruang yang dituangkan dalam bentuk pilihan ganda dan uraian baik dalam LKPD maupun KUIS sesuai dengan instrumen yang telah dikategorikan valid, praktis dan efektif; 4) Perumusan tujuan pembelajaran, Adapun tujuan pembelajaran ini adalah menjawab dari hal yang ingin dicapai dalam pembelajaran matematika menggunakan pendekatan neuroscience.

\section{Tahap II : Perancangan (Design)}

Hasil rancangan ini meliputi tahap perancangan seperti.(1) Penyusunan tes, (2) Pemilihan Media Pembelajaran, dan (3) Pemilihan format.

Tahap III : Pengembangan (Develop): 1) Pengembangan draft awal, Draft awal perangkat pembelajaran ini meliputi Silabus, RPP, Buku Siswa, LKPD dan Tes Hasil Belajar. Silabus ini merupakan pengarah dari pelaksanaan pembelajaran yang nantinya akan dilaksanakan; 2) Validasi perangkat oleh para Pakar diikuti dengan revisi, Pembahasan hasil penilaian oleh para ahli. Revisi bahan pengajaran (Instructional revitions) dilakukan melalui Revisi oleh para ahli.Revisi para ahli terlebih dahulu dilakukan validasi; 3) Uji Coba Terbatas, Uji coba dilakukan sebanyak lima kali pertemuan mulai 
tanggal 24 Februari 2018 sampai 24 April 2018. Rancangan awal perangkat pembelajaran dalam hal ini Draft 1 divalidasi oleh ahli dalam bidang pendidikan matematika dengan komputer.

Uji Analisis data Kevalidan perangkat
pembelajaran

Adapun kriteria yang digunakan sebagai berikut.

Tabel 1. Rangkuman Hasil Validasi Perangkat Pembelajaran

\begin{tabular}{|c|c|c|}
\hline Sumber & Skor Rata-rata & Kriteria \\
\hline RPP & 4,1 & Valid \\
\hline Buku siswa & 4,1 & Valid \\
\hline LKPD & 4,2 & Valid \\
\hline Tes Hasil Belajar & 4,0 & Valid \\
\hline
\end{tabular}
pembelajaran tersebut telah layak untuk diujicobakan. Namun, berdasarkan saran dari para ahli masih ada yang perlu diperbaiki/ditambah. Setelah dilakukan beberapa revisi berdasarkan masukan dari validator dihasilkan perangkat pembelajaran draft 2, kemudian di ujicobakan.

Uji Analisis data Kepraktisan perangkat pembelajaran

Analisis data kepraktisan perangkat pembelajaran disini adalah analisis data keterlaksanaan perangkat pembelajaran matematika menggunakan pendekatan neuroscience.

Uji Analisis data Keefektifan perangkat pembelajaran

Analisis data Keefektifan perangkat pembelajaran telah dikemukakan sebelumnya, dikatakan bahwa perangkat pembelajaran efektif apabila memenuhi tiga indikator yakni: 1) Ketercapaian hasil belajar. Ketercapaian hasil belajar itu ditunjang oleh tes hasil belajar yang baik dalam hal ini tuntas. Persentase ketuntasan secara klasikal adalah 93,33\% sehingga hal ini menunjukkan bahwa ketuntasan klasikal telah tercapai; 2) Aktivitas Siswa. Berdasarkan pengamatan aktivitas siswa sebagaimana telah diuraikan di atas, diketahui semua kategori aktivitas siswa yang diamati memenuhi Interval Toleransi PWI (\%) yang ditentukan dan aktivitas siswa berada pada kategori aktif; 3) Respons Siswa. Ada tiga aspek yang menjadi fokus respons siswa terhadap kegiatan pembelajaran berbasis model kooperatif pendekatan neuroscience berdasarkan angket respons yang berikan kepada siswa, di peroleh bahwa respons siswa terhadap perangkat pembelajaran semua berada pada kategori positif.

\section{Tahap IV : Penyebaran (Disseminates)}

Diseminasi/Penyebaran perangkat pembelajaran hanya bersifat sosialisasi secara terbatas kepada SD Negeri 42 Waetuwo dengan tujuan untuk mendapatkan masukan, koreksi, saran untuk menyempurnakan produk akhir pengembangan agar siap diadopsi oleh para pengguna produk.

\section{Pembahasan Penelitian}

Penelitian ini menggunakan jenis penelitian pengembangan. Menurut Sugiyono (2012) penelitian pengembangan adalah metode penelitian yang digunakan untuk menghasilkan produk tertentu, kemudian menguji keefektifan produk tersebut. Berdasarkan uraian di atas maka dapat disimpulkan bahwasanya pengembangan perangkat pembelajaran merupakan suatu bentuk prosedur yang dimana dilakukan secara terarah dan sistematis untuk menghasilkan suatu perangkat pembelajaran berdasarkan teori pengembangan yang telah ada.

Pandangan mengenai keterkaitan neuroscience dalam proses belajar mengajar telah banyak dilakukan dan sangat berpengaruh baik untuk melatih siswa dalam menggunakan otak dalam belajar. Masson (2012) menjelaskan neuroscience tidak hanya memandang bahwa bagaimana otak diajarkan sebuah pengetahuan baru, melainkan menggunakan otak bekerja sebagaimana fungsinya. Pendekatan dalam pembelajaran neurosciencet idak dapat berdiri sendiri, untuk itu guru juga dituntut untuk mampu menggunakan perangkat pembelajaran yang inovatif agar proses pembelajaran yang berlangsung dapat lebih bermakna dan melekat dalam ingatan siswa. Beberapa teknik dalam pembelajaran neuroscienceyang dapat diintegrasikan dalam perangkat pembelajarannya untuk melatih siswa dalam mengingat sebuah materi pelajaran sehingga diharapkan daya ingat siswa dalam memahami dan mengingat pembelajaran bertahan lama. 
Prosedur pembelajaran neuroscience dalam perangkat pembelajaranyang diadaptasi dari beberapa model pembelajaran yang lebih mengutamakan fungsi otak dalam pembelajaran, tahapan tersebut ada tujuh tahapan pembelajaran berbasis kemampuan otak (Rudi, 2015), sebagai berikut: 1) Pra-Pemaparan. Tahap ini memberi gambaran awal terhadap pembelajaran baru sebelum dikaji lebih jauh dan mendalam. Pra-pemaparan membantu otak membangun peta konseptual yang lebih baik; 2) Persiapan. Dalam tahap ini, Fasilitator menciptakan keingintahuan dan kesenangan; 3) Inisiasi dan akuisisi. Tahap ini merupakan tahap penciptaan koneksi atau pada saat neuronneuron itu saling "berkomunikasi" satu sama lain; 4) Elaborasi. Tahap elaborasi memberikan kesempatan kepada otak untuk menyortir, menyelidiki, menganalisis, menguji, dan memperdalam pembelajaran; 5) Inkubasi dan memasukkan memori. Tahap ini menekankan bahwa waktu istirahat dan waktu untuk mengulang kembali merupakan suatu hal yang penting; 6) Verifikasi dan pengecekan keyakinan. Dalam tahap ini, fasilitator mengecek apakah peserta sudah paham dengan materi yang telah dipelajari atau belum; 7) Perayaan dan integrasi. Tahap ini menanamkan semua arti penting dari kecintaan terhadap belajar.

Model pengembangan perangkat yang digunakan dalm penelitian ini yaitu model Four$D$ yang disarankan oleh Sivasailam, Thiagarajan, Dorothy S, Semmel dan Melvyn I, Semmel. Adapun Tahap-tahap pengembangan 4-D yaitu sebagai berikut: 1) Tahap I Pendefinisian (Define); 2) Tahap II Perancangan (Design); 3) Tahap III Pengembangan (Develop); 4) Tahap IV Penyebaran (Desseminates)

Adapun inti dari penelitian ini adalah sebagai berikut.

Kevalidan

Perangkat pembelajaran yang telah disusun termasuk dalam kevalidan. Hal ini dipertegas oleh data yang diperoleh dari hasil validitas tiga orang validator yang ahli dibidang pendidikan matematika dan komputer spesialis Multimedia ini, menunjukkan bahwa rata-rata penilaian atau hasil validasi dari para ahli pada perangkat pembelajaran yang digunakan meliputi RPP, Buku siswa, LKPD, Tes Hasil Belajar, dan pembelajaran berbasis model kooperatif pendekatan neuroscience berada pada kategori "Valid" 3,5 $\leq \bar{V}<4,5$. Sehingga dapat dikatakan bahwa perangkat pembelajaran menggunakan pendekatan neuroscience tersebut telah layak untuk diujicobakan.

Kepraktisan

Berdasarkan hasil uji coba terbatas yang mengungkapkan nilai kepraktisan diperoleh dari hasil observasi dari para observer yang sebelumnya telah ditunjuk untuk menilai sejauhmana pengelolaan pembelajaran ini telah dilaksanakan di sekolah.

\section{KESIMPULAN}

Proses pengembangan

perangkat pembelajaran matematika mengunakan pendekatan neuroscience yang valid, praktis dan efektif dilaksanakan dengan empat tahap yaitu: (1) Tahap Pendefinisian, menghasilkan masalahmasalah awal sehingga dilakukan pengembangan perangkat, (2) Tahap Perancangan, menghasilkan rancangan perangkat pembelajaran, (3) Tahap Pengembangan, menghasilkan perangkat pembelajaran yang telah direvisi berdasarkan masukan dari para ahli, dan data yang diperoleh dari hasil uji coba, dan (4) Tahap Penyebaran, dilakukan sosialisasi kepada guru-guru yang ada di sekolah penelitian.

Hasil pengembangan perangkat pembelajaran matematika menggunakan pendekatan neuroscience yang valid, praktis dan efektif yaitu: 1) Kevalidan hasil pengembangan perangkat pembelajaran matematika menggunakan pendekatan neuroscience yaitu perangkat pembelajaran secara keseluruhan berada pada rata-rata kevalidan ( $\bar{V})$ 4,1 valid dan layak digunakan; 2) Kepraktisan hasil pengembangan hasil pengembangan perangkat pembelajaran matematika menggunakan pendekatan neuroscience yaitu Kategori kepraktisan terlaksana dengan baik; 3) Keefektifan hasil pengembangan hasil pengembangan perangkat pembelajaran matematika menggunakan pendekatan neuroscience diperoleh ketercapaian hasil belajar mencapai standar KKM 70; 4) Aktivitas guru 
dalam mengelola pembelajaran matematika menggunakan pendekatan neuroscience yaitu kategori aktivitas guru terlaksana dengan baik; 5) Aktivitas siswa dalam mengelola pembelajaran matematika menggunakan pendekatan neuroscience yaitu kategori aktivitas siswa berada dalam kategori aktif; 6) Respons siswa terhadap pembelajaran matematika menggunakan pendekatan neuroscience yaitu kategori respons berada pada respon positif.

\section{DAFTAR PUSTAKA}

Cercone, K. 2008. Characteristics of Adult Learners with Implications for Online Learning Design. AAACEJournal. 16(2); 137159.ISSN 1978-5089.

Masson, S. 2012. Neuroeducation: understanding the brain to improve teaching. Jounal Neuroeducation (Association for Research in Neuroeducation). 1(1): 1-2.

Nuraeni. L. 2014. Pendidikan Berbasis Neuropedagogis. Jurnal Ilmiah STKIP Siliwangi Bandung. 8 (1); 11-20. ISSN 1978. 5089.

Nurdin. 2007, Model Pembelajaran yang Menumbuhkan Kemampuan Metakognitif, Disertasi tidak dipublikasikan, Program Pascasarjana Unesa, Surabaya.

Nurkancana, W \& Sumartana. 1986. Evaluasi Pendidikan. Surabaya: Usaha Nasional.

Rudi. 2015. Peranan Neuroandragogi pada Pendidikan Orang Dewasa. ArtikelEBuletinLPMP Sulsel. Hal. 1-10. ISSN. 2355 3189.

Santrock, J. W. 2007. Psikologi Pendidikan (Edisi Kedua). Jakarta: Kencana.

Schunk, DH. 2012. Learning Theories an Educational Perspektif, Cet. 1. Pustaka Pelajar.Yogyakarta.

Sirwanti. 2016. Pengembangan Perangkat Pembelajaran Matematika menggunakan Pendekatan Scientific pada Siswa Kelas V SDN 43 Pallette. Jurnal Pendidikan MIPA, Vol. 6 No. 2, Juli- Desember 2016 ISSN 2088-0294

Suyadi. 2012. Integrasi Pendidikan Islam dan Neurosains dan Implikasinya Bagi
Pendidikan Dasar (PGMI). Jurnal Al-Bidāyah. 4 (1): 111-130.

Wahyu, H. 2014. Mengembangkan Retensi Kemampuan Berpikir Tingkat Tinggi Matematis Siswa SMP Melalui Pendekatan Kontekstual. Jurnal Prosiding Seminar Nasional pendidikan matematika.27 Nopember 2014, Bandung. Hal 32-44.

Wathon. Aminul. 2012. Neurosains Dalam Pendidikan. Jurnal Lentera, Kajian Keagamaan, Keilmuan dan Teknologi. 1 (3):136-145. ISSN: 1693-6922. 